Psychopharmacology 51, 189-193 (1977)

\title{
Intracranial Reward after Lilly 110140 (Fluoxetine HCl): Evidence for an Inhibitory Role for Serotonin
}

\author{
R. J. KATZ and B. J. CARROLL \\ Mental Health Research Institute, Department of Psychiatry, University of Michigan, Ann Arbor, Michigan 48109, U.S.A.
}

\begin{abstract}
The 5-hydroxytryptamine (5-HT, serotonin) specific presynaptic reuptake inhibitor Lilly 110140 (fluoxetine hydrochloride) was injected systemically in rats trained to bar-press for rewarding stimulation to the caudal portion of the medial forebrain bundle. Rates of self stimulation were reduced in proportion to drug dosage, and these reductions were partially reversible by methysergide. These findings are consistent with previous reports suggesting an inhibitory role for 5-HT in self stimulation.
\end{abstract}

Key words: Brain stimulation - Fluoxetine 5-Hydroxytryptamine - Methysergide - Self stimulation - Serotonin.

The phenomenon of intracranial self stimulation has come under ever increasing biochemical and pharmacological scrutiny, and recent findings point to the importance of several biogenic amines in its regulation. In particular, one or more catecholamines appear to be necessary for the maintenance of this behavior (Belluzzi et al., 1975; Broekkamp and van Rossum, 1974; Clavier and Routtenberg, 1974; Crow, 1972a,b; Phillips and Fibiger, 1973; Poschel and Ninteman, 1963, 1966; Stein, 1962, 1968; Ritter and Stein, 1973, 1974; Stinus and Thierry, 1973; Wauquier and Niemegeers, 1973; Wise et al., 1973), while the indolealkylamine serotonin (5-HT) appears to serve a complementary inhibitory role.

Evidence for the inhibitory role of 5-HT in intracranial self stimulation includes precursor loading (Bose et al., 1974) and the administration of exogenous neurotransmitter directly into the cerebral ventricles (Wise et al., 1973), both of which decrease rates of response. Conversely, pharmacological blockade of serotonin biosynthesis by the tryptophan hydroxylase inhibitor para-chlorophenylalanine (Blum and Geller, 1969; Gibson et al., 1970; Koe and Weisman, 1966; Poschel and Ninteman, 1971) as well as biochemical lesions with 5, 6 dihydroxytryptamine (Poschel et al., 1975 ) cause increased responding. Despite the above evidence for serotonergic inhibition of brain stimulation reward however, several workers have reported possibly discrepant results, both with regard to serotonergic potentiation causing rate decreases (Poschel and Ninteman, 1968) and serotonergic depletion causing rate increases (e.g., Black and Cooper, 1970; Cooper et al., 1971; Lorens, 1971; Margules, 1969; Miliaressis et al., 1975; Stark et al., 1970). Such negative findings may call into question the biochemical specificity of a given treatment or treatments, or alternately point to perhaps more fundamental theoretical complications.

The development of a novel, biochemically specific serotonin reuptake inhibitor, Fluoxetine (Fuller et al., $1974 \mathrm{a}, \mathrm{b}, 1975 \mathrm{a}, \mathrm{b}, \mathrm{c})$, allows additional examination of the role of 5-HT in the self stimulation process. If 5-HT does normally inhibit self stimulation then administration of such an inhibitor of 5-HT reuptake should systematically decrease self-stimulation rates, and this inhibition should be reversible by blockade of postsynaptic 5-HT receptors. The present experiments were designed to test these hypotheses.

\section{METHODS}

Subjects. The subject pool consisted of 10 adult male rats of the Sprague-Dawley strain obtained locally (Spartan Farms, Haslett, Mich.) and weighing $300-450 \mathrm{~g}$. All subjects were housed individually with food and water continuously available throughout the experiment. Daily cycles of $12 \mathrm{hlight} / 12 \mathrm{~h}$ darkness were maintained by artificial lighting.

Surgery. Subjects were anesthetized with $35 \mathrm{mg} / \mathrm{kg}$ sodium pentobarbital (Nembutal) administered intraperitoneally. Each subject received a stereotaxic implant with a single bipolar stainless steel 
electrode made of $0.01 \mathrm{~mm}$ diameter wire insulated to the tip. All electrodes were aimed at the medial forebrain bundle (Konig and Klippel, 1963) and subjects were allowed 1 week to recover prior to any testing.

Apparatus. Subjects were tested in $20 \times 25 \times 30 \mathrm{~cm}$ wooden chambers with plexiglass tops. A single $8.9 \mathrm{~cm}$ width lever was located $6.7 \mathrm{~cm}$ from the chamber floor, and operated a microswitch with a pressure requirement of $25.0 \mathrm{~g}$. A constant level of approximately $30 \mathrm{~dB}$ background noise was provided by a General Radio 1380-A white noise generator.

Drugs. Lilly 110140 (Fluoxetine); 3-(-p-trifluoromethylphenoxy-nmethyl-3-phenylpropylamine) was injected in dosages of $0,1,5$, and $10 \mathrm{mg} / \mathrm{kg}$ in a sterile saline vehicle. All injections were administered intraperitoneally in a volume of $1 \mathrm{ml} / \mathrm{kg}$ between minutes 25 and 30 of a given self-stimulation session. Dosages were based upon the established biochemistry of the drug (Fuller et al., 1974a,b; $1975 \mathrm{a}, \mathrm{b}, \mathrm{c})$. Previous reports indicated that the dosages employed interfered selectively with serotonin reuptake, without affecting the central disposition of other biogenic amines. Methysergide maleate $(1 \mathrm{mg} / \mathrm{kg})$ was injected with a distilled water vehicle between minutes 120 and 150 of the test session. Dosage of methysergide was based upon previously published reports (Phillips and Wray, 1975; Clineschmidt et al., 1974; Cook and Sepinwall, 1975). The placebo injection for methysergide consisted of distilled water. The order of drug presentation was random across sessions.

Behavioral Procedure. Subjects were initially trained to bar-press for a reinforcement of intracranial reward. Each reinforcement consisted of a $0.2 \mathrm{~s}$ train of $60 \mathrm{cycle} / \mathrm{s}$ sinusoidal current delivered through a $50 \mathrm{~K} \Omega$ resistor and across a zero-crossing relay to maintain approximately constant current conditions. Current was continually monitored through a $100 \Omega$ resistor in series with the subject upon a 130-B Hewlett-Packard oscilloscope.

Five of the rats were given five 220-min training sessions spaced $48 \mathrm{~h}$ apart. During this initial period current was adjusted so that each subject responded at a high, stable rate $(1000-5000$ respon$\mathrm{ses} / \mathrm{h}$ ). Final current values ranged from $50-100 \mu \mathrm{A}$. Eight additional sessions were run for each subject, during which one of 4 dosages of Fluoxetine was administered, with or without an attempted pharmacological reversal in each case. Responses were recorded continuously for all sessions, and were analyzed either as successive 30-min blocks, or, in the case of reversal testing, as the 15-min block subsequent to methysergide injection. The remaining rats were used to replicate the initial dose-tesponse relationship for the two highest dosages of fluoxetine, and to evaluate the effects of vehicle administration for the time period when the original five subjects were receiving methysergide. Control injections for methysergide were not administered to the first group in order to obtain uninterrupted records of fluoxetine effects.

Statistics. Drug effects (i.e., Fluoxetine) and reversal effects (i.e., methysergide) were expressed as percentage of vehicle $(0 \mathrm{mg} / \mathrm{kg})$ control, and were evaluated by a treatments by treatments by subjects analysis of variance, with repeated measures upon all factors. Drug teversal was evaluated by within subjects $t$ tests comparing the 15-min preceeding methysergide injection, and the following 15-min period (Dixon and Massey, 1969). Analyses were run separately for each of the two groups. Given the nature of the experimental hypothesis, directional tests of significance were employed for all comparisons.

Histology. At the close of testing all subjects were injected with an overdose of Nembutal, and perfused initially with normal saline and subsequently with formalin-alcohol-acetic acid fixing solution (Luna, 1960). The brains were removed, sliced in $40 \mu$ sections and stained with cresyl violet. Microscopic examination revealed that all sites were located in the caudal medial forebrain bundle (Fig. 1).

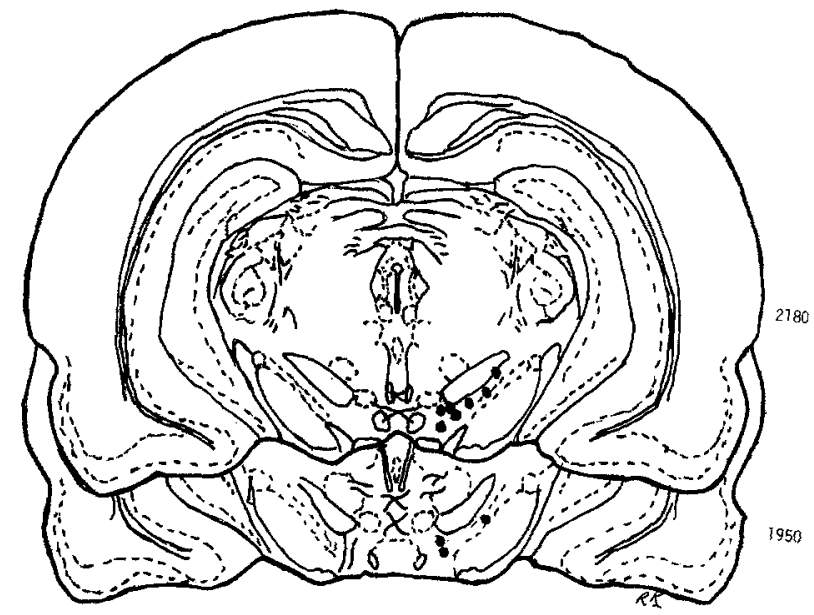

Fig. 1. Composite histology of self-stimulation sites (sections redrawn after the Atlas of Konig and Klippel, 1963) coordinates in $\mu$
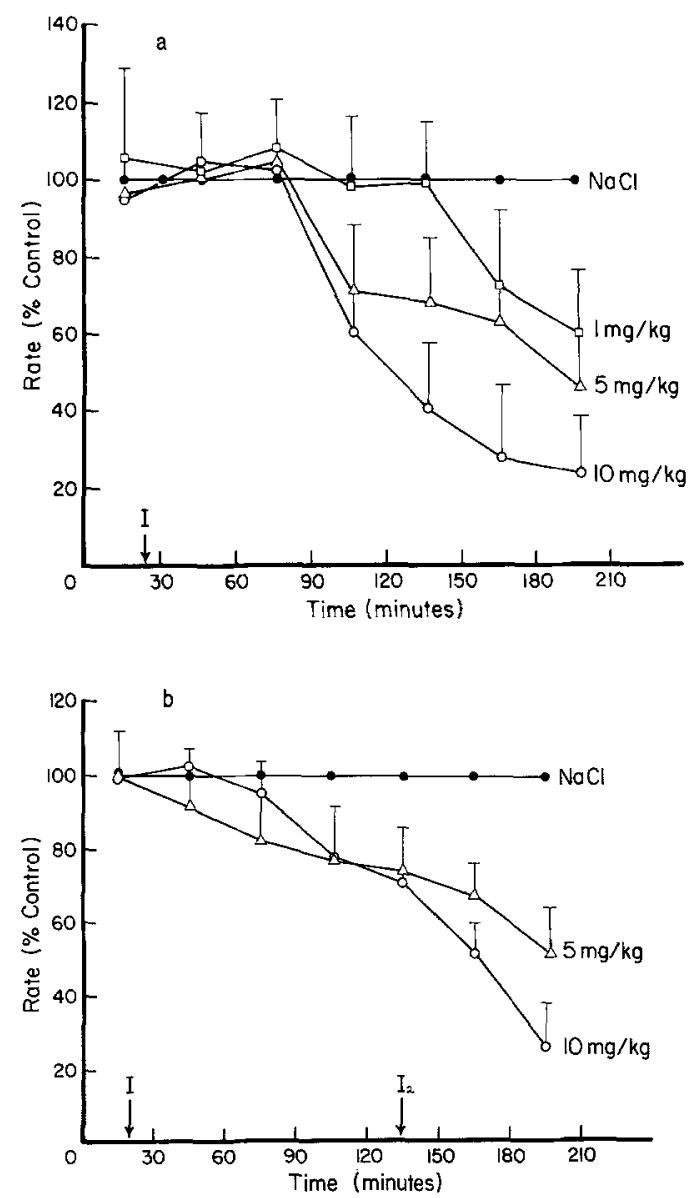

Fig. $2 a$ and $b$. Effects of Fluoxetine upon intracranial self stimulation in the rat. All values are expressed as mean percent of control $(\mathrm{NaCl})+$ percent standard error, $I$ injection of Fluoxetine, $I_{2}$ methysergide vehicle injection. (a) First group (no methysergide vehicle); (b) Second group (methysergide vehicle injected) 

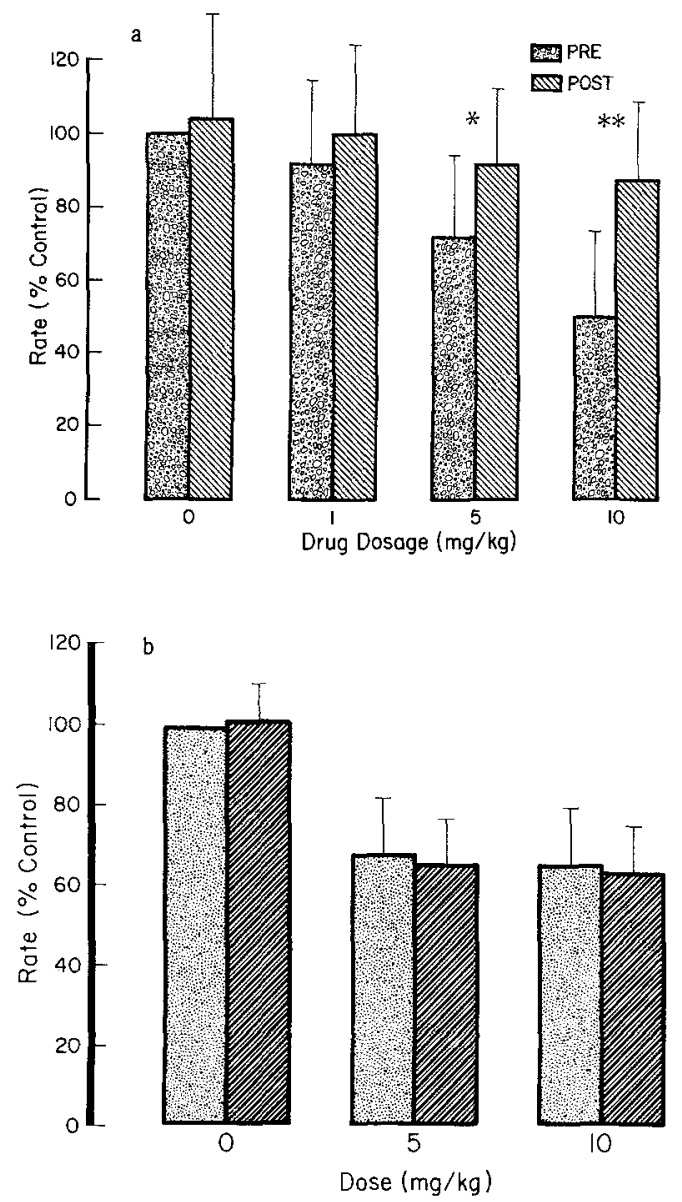

Fig. $3 \mathrm{a}$ and b. Methysergide $(1 \mathrm{mg} / \mathrm{kg})$ effect upon 4 dosages of Fluoxetine. All values are expressed as mean percent control + percent standard error; ${ }^{*} P<0.05 t$ test for related means (1-tailed criterion); ${ }^{* *} P<0.05 t$ test for related means (2-tailed criterion). (a) First group, no vehicle injection (control is baseline response rate); (b) Second group, methysergide vehicle (control is vehicle injected)

\section{RESULTS}

Fluoxetine caused a dose-related decrease in responding, beginning approximately $100 \mathrm{~min}$ after injection and persisting throughout the entire testing session (Fig. 2a). These results are consistent with the established time course of this drug (Fuller et al., 1975c; Wong et a1., 1975). Although rates were substantially reduced the rats did not appear to be grossly sedated, and remained in the vicinity of the bar, pressing at lower rates. Analysis of variance yielded significant effects of time $\left(F_{6,24}=3.3 ; P<0.05\right)$, drug $\left(F_{3,12}\right.$ $=4.7 ; P<0.05)$, and interaction $\left(F_{18,72}=2.8\right.$; $P<0.05$ ). It may be seen in Figure $2 \mathrm{~b}$ that essentially similar results were found for the second group, with significant effects for time $\left(F_{6,24}=4.1 ; P<0.05\right)$, drug $\left(F_{2,6}=5.3 ; P<0.05\right)$ and interaction $\left(F_{12,48}\right.$ $=2.7 ; P<0.05)$.
Methysergide produced only slight changes in response rate at 0 and $1 \mathrm{mg} / \mathrm{kg}$ of fluoxetine $(t=1.2$ and 1.3 respectively, $d f=4 ; P<0.05$ ). However, methysergide reversed fluoxetine-induced depression of self-stimulation at 5 and $10 \mathrm{mg} / \mathrm{kg}$ doses of the latter (Fig. 3a). This reversal was significant at $5 \mathrm{mg} / \mathrm{kg}$ using a 1-tailed criterion $(t=2.3, d f=4 ; P<0.05)$, and at $10 \mathrm{mg} / \mathrm{kg}$ using a 2-tailed criterion $(t=3.4$, $d f-4 ; P<0.05$ ). In addition, it may be seen in Figure $3 b$ that vehicle injection had virtually no effect upon local rates of response ( $t$ ratios for 0,5 , $10=0.8,0.6,0.7$ respectively, $d f=4, P>0.05$ ).

\section{DISCUSSION}

To our knowledge the present report represents the first use of fluoxetine in a behavioral experiment ${ }^{1}$. The results support the hypothesis that serotonin serves an inhibitory role in self stimulation. Fluoxetine caused significant reductions in self stimulation rates, and these were reversed by the serotonin receptor blocker methysergide. Although recent neuropharmacological evidence (Haigler and Aghajanian, 1974) suggests that methysergide antagonizes only a small proportion of central serotonin responsive neurons, the success of the present manipulations suggests that at least some of these neurons were in fact affected.

Roll (1970) has argued that alterations in ICS rates must be evaluated not only in terms of the changed reward value of stimulation but also in terms of possible altered alertness. We have already noted that visual observations of the subjects revealed no overt increases in sedation at the present doses. Moreover, since the side effects of methysergide include sedation, confusion and ataxia (Douglas, 1976) and since injection of methysergide increased rather than decreased response rates, an interpretation of the present results entirely in terms of altered alertness is implausible.

Acknowledgements. The authors gratefully acknowledge postdoctoral support provided to the first author from the National Institutes of Health, through the University of Michigan (07417). We are grateful to Roy Fuller of the Lilly Research Laboratories for his kind donation of Lilly 110140 . The expert technical assistance of $\mathrm{G}$. Baldrighi is also gratefully acknowledged.

\footnotetext{
1 Coincident with the initial submission of this manuscript Miliaressis and Jacobowitz (1976) reported relatively modest reductions in ICS rates after a different schedule of Fluoxetine administration. Given the different CNS sites, injection schedules and behavioral procedures employed there is nonetheless at least general consistency between their results and the present report.
} 


\section{REFERENCES}

Belluzzi, J. D., Ritter, S., Wise, C. D., Stein, L.: Substantia nigra self stimulation: Dependence upon noradrenergic reward pathways. Behav, Biol. 13, 103-111 (1975)

Black, W. C., Cooper, B. R.: Reduction of electrically rewarded behavior by interference with monamine synthesis. Physiol. Behav. 5, 1405-1409 (1970)

Bose, S., Bailey, P. T., Thoa, N. B., Pradhan, S. N.: Effects of 5-hydroxytryptophane on self stimulation in rats. Psychopharmacologia (Berl.) 36, 255-262 (1974)

Blum, K., Geller, I.: Facilitation of brain stimulation with parachlorophenylalanine. Fed. Proc. 28, 794 (1969)

Broekkamp, C. L. E., van Rossum, J. M.: Effects of apomorphine on self stimulation behavior. Psychopharmacologia (Berl.) 34, $71-80(1974)$

Clavier, R. M., Routtenberg, A.: Ascending monoamine-containing fiber pathways related to intracranial self stimulation: histochemical fluorescence study. Brain Res. 72, 25-40 (1974)

Clineschmidt, B. V., McGuffin, J. C., Werner, A. B.: Role of monoamines in the anorexigenic actions of fenfluramine, amphetamine, and p-chloromethamphetamine. Europ. J. Pharmacol. 27, $313-323(1974)$

Cook, L., Sepinwall, J.: Behavioral analysis of the effects and mechanisms of action of benzodiazepines. In: Advances in biochemical psychopharmacology, Vol. 14, E. Costa and P. Greengard, eds. New York: Raven Press 1975

Cooper, B. R., Black, W. C., Paolina, R. M.: Decreased septalforebrain and lateral hypothalamic reward after $\alpha$-methyl paratyrosine. Physiol. Behav. 6, 425-429 (1971)

Crow, T. J.: A map of the rat mesencephalon for electrical self stimulation. Brain Res. 36, 265-273 (1972a)

Crow, T. J.: Catecholamine containing neurons and electrical self stimulation: I. A review of some data. Psychol. Med. 2, 414-421 (1972b)

Dixon, W. J., Massey, F. J.: Introduction to statistical analysis, 3rd ed. New York: McGraw-Hill 1969

Douglas, W. W.: Histamine and antihistamines; 5-hydroxytryptamine and antagonists. In: The pharmacological basis of therapeutics, L. Goodman and A. Gilman, eds., 5th ed., pp. 596-630. New York: MacMillan 1975

Fuller, R. W., Perry, K. W.: Inability of an inhibitor of amine uptake (Lilly 110140) to block depletion of brain 5-hydroxytryptamine by L-Dopa. J. Pharm. Pharmacol. 27, 618-619 (1975a)

Fuller, R. W., Perry, K. W., Molloy, B. B.: Effect of an uptake inhibitor on serotonin metabolism in the rat brain: Studies with 3-(-p-trifluoromethylphenoxy)-N-methyl-3-phenylpropylamine (Lilly 110140). Life Sci. 15, $1161-1171$ (1974a)

Fuller, R. W., Perry, K. W., Molloy, B. B.: Effect of 3-(-p-trifluoromethylphenoxy)-N-methyl-3-phenylpropylamine on the depletion of brain serotonin by 4-chloroamphetamine. J. Pharmacol. exp. Ther. 193, 796-803 (1975b)

Fuller, R. W., Perry, K. W., Molloy, B. B.: Reversible and irreversible phase of serotonin depletion by 4-chloroamphetamine. Europ. J. Pharmacol. 33, 119-124 (1975c)

Fuller, R. W., Perry, K. W., Snoddy, H. D., Molloy, B. B.: Comparison of the specificity of 3-(p-trifluoromethylphenoxy)-Nmethyl-3-phenylpropylamine as amine uptake inhibitors in mice. Europ. J. Pharmacol. 28, 233-236 (1974b)

Gibson, S. E., McGeer, E. G., McGeer, P. L.: Effect of selective inhibitors of tyrosine and tryptophan hydroxylases on self stimulation in the rat. Exp. Neurol. 27, 283-290 (1970)

Haigler, H. J., Aghajanian, G. R.: Peripheral serotonin antagonists: Failure to antagonize serotonin in brain areas receiving a prominent serotonin input. J. Neur. Trans. 35, 257-273 (1974)
Koe, B. K., Weissman, A.: P-chlorophenylalanine: A specific depletor of brain serotonin. J. Pharmacol. exp. Ther. 154, 499-561 (1966)

Konig, J. F. R., Klippel, R. A. : The rat brain-A stereotaxic atlas of the forebrain and lower parts of the brain stem. New York: Williams and Wilkins 1963

Lorens, S.: Effect of lesions of the raphe system on self stimulation in the rat. Physiol. Behav. 7, 815-818 (1971)

Luna, L. G.: Manual of histological staining methods of the armed forces Institute of Pathology. New York: McGraw-Hill 1960

Margules, D. L.: Noradrenergic rather than serotonergic basis of reward in the dorsal tegmentum. J. comp. physiol. Psychol. 67, $32-35(1969)$

Miliaressis, E., Bouchard, A., Jacobowitz, D.: Strong positive reward in the median Raphe, specific inhibition by para chlorophenylalanine. Brain Res. 98, 194-199 (1975)

Miliaressis, E., Jacobowitz, D.: Hyperthermia following self-stimulation of the median Raphe. Pharm. Biochem. Behav. 4, 477-479 (1976)

Phillips, A. G., Fibiger, H. C.: Dopaminergic and noradrenergic substrates of positive reinforcement: differential effects of d- and 1-amphetamine. Science 179, 575-576 (1973)

Phillips, K. C., Wray, S. E.: Failure of anti-serotonergic agents to modify levallorphan induced stereotypy in rats. Psychopharmacologia (Berl.) 41, 263-265 (1975)

Poschel, B. P. H., Ninteman, F. W.: Norepinephrine: a possible excitatory neurohormone of the reward system. Life Sci. 2, $782-788(1963)$

Poschel, B. P. H., Ninteman, F. W. : Hypothalamic self stimulation: its suppression by blockade of norepinephrine biosynthesis and reinstatement by methamphetamine. Life Sci. 5, 11-16 (1966)

Poschel, B. P. H., Ninteman, F. W.: Excitatory effects of 5-HTP on intracranial self stimulation following MAO blockade. Life Sci. 7, 317-323 (1968)

Poschel, B. P. H., Ninteman, F. W.: Intracranial reward and the forebrain's serotonergic mechanism: studies employing parachlorophenylalanine and para-chloroamphetamine. Physiol. Behav. 7, 39-46 (1971)

Poschel, B. P. H., Ninteman, F. W., McLean, J. R., Potoczah, D.: Intracranial reward after 5, 6, dihydroxytryptamine: Further evidence for serotonin's inhibitory role. Life Sci. 15, 1515-1522 (1975)

Ritter, S., Stein, L.: Self stimulation of the noradrenergic cell group $\left(A_{6}\right)$ in locus coeruleus of rats. J. comp. physiol. Psychol. 85, $443-452(1973)$

Ritter, S., Stein, L.: Self stimulation in the mesencephalic trajectory of the ventral noradrenergic bundle. Brain Res. 81, 145--157 (1974)

Roll, S. K.: Intracranial self stimulation and wakefulness, effects of manipulating ambient brain catecholamines. Science 168, $1370-1372(1970)$

St.-Laurent, J., Leclerc, R. R., Mirchell, M. L., Milliaressis, T. E.: Effects of apomorphine on self stimulation. Pharmacol. Biochem. Behav. 1, 581 (1973)

Stark, P., Fuller, R. W., Hartley, L. W., Schaffer, R. J., Tuch, J. A. Dissociation of the effects of p-chlorophenylalanine on self stimulation. Life Sci. 9, 41-48 (1970)

Stein, L.: Effects and interactions of imipramine, chlorpromazine, reserpine and amphetamine on self stimulation: Possible neurophysiological basis of depression. In: Recent advances in biological psychiatry, J. Wortis, ed., pp. $288-308$. New York: Plenum 1962

Stein, L. : Chemistry of reward and punishment. In: Psychopharmacology: A review of Progress 1957-1967, D. H. Efron, ed., p. 105. Washington: U. S. Government Printing Office 1968

Stinus, L., Thierry, A. M.: Self stimulation and catecholamines. II. Blockade of self stimulation by treatment with alpha-methyl- 
paratyrosine and the reinstatement by catecholamine precursor administration. Brain Res. 64, 189 (1973)

Ungerstedt, U.: Stereotaxic mapping of the monoamine pathways in rat brain. Acta physiol. scand., Suppl. 367, 1-48 (1971)

Wauquier, A., Niemegeers, C. J. E.: Intracranial self stimulation in rats as a function of various stimulus parameters. II. Influence of haloperidol, pimozide and pepamperone on medial forebrain bundle stimulation with monopolar electrodes. Psychopharmacologia (Berl.) 27, 191-202 (1972)
Wise, C. D., Berger, B. D., Stein, L.: Evidence of $\alpha$-noradrenergic reward receptors and serotonergic punishment receptors in the rat brain. Biol. Psychiat. 6, 3-22 (1973)

Wong, D. T., Bymaster, F. R., Horing, J. S., Molloy, B. B.: A new selective inhibitor for uptake of serotonin into synaptosomes of rat brain (3-p-triffuoromethylphenoxy)-n-methyl-3-phenylpropylamine. J. Pharmacol. exp. Ther. 193, 804-811 (1975)

Received June 26, 1976 